\title{
Travelling with a purpose: an ethnographic study of the eudemonic experiences of volunteer expedition participants
}

\begin{abstract}
Purposeful travel is apparent in new modes of tourism and particularly in volunteer holidays where tourists are searching for meaningful experiences that provide a sense of physical, emotional or spiritual fulfilment. Based on a qualitative study using participant observation, this paper adopted the concept of eudemonia to explore the experiences of participants on an elephant conservation expedition to Bardia National Park, Nepal.

Volunteer travel is used to connect with and understand the wider world. Rather than an escape, these journeys allowed participants to experience first-hand the hardships and realities of people in other countries; creating greater perspective and making them 'better people' on their return. Feeling virtuous can only be mobilised, however, if participants felt themselves to be useful rather than a passive or ill-equipped bystander. Findings also revealed how the return home is not always easy; that the process of reentry can be isolating.
\end{abstract}

\section{Key words}

Volunteer tourism, self-development, eudemonia, ethnography. 


\section{Introduction}

Volunteer tourism is one of the major growth areas in contemporary tourism (Wearing, Benson and McGehee (2016). According to Young (2008, 207), it "is an expanding sector of the tourism industry in many countries in both the developed and the developing world" and is an outcome of increased travel opportunities, a rising middle class and a desire to seek out more meaningful and unusual modes of tourism. The exact volume and value of volunteer travel are largely unknown given the number of tour operators and global volunteering opportunities but there are estimations of its contribution to the tourism economy. Given the significance of this sector, research concerned with individual volunteer experiences is a major focus (Alexander 2012; Noy 2004). Volunteer travel is promoted as a way to 'give something back' (Grabowski and Wearing 2011), to learn new skills and meet like-minded people whilst enjoying the benefits of travel to often exotic or peripheral destinations (Brown 2005). But what expectations do volunteers have? How does volunteer travel contribute to a 'meaningful life' and what positive and negative emotions do participants bring to co-create the volunteer experience? These are important questions for the facilitators of these unique tourist experiences. 
This paper investigates the answers to these questions by exploring the eudemonic outcomes of volunteering that derive from both altruism and egoism, and the proposition that the two are not mutually exclusive. Using data from an ethnographic study of volunteers on a conservation expedition in Nepal, the focus is on the quest for purposeful travel which combines altruistic intentions with self-development and personal meaning. This puts a new perspective on volunteer travel beyond the already researched and often polarised paradigms of egoism versus altruism. To date only a few authors have considered eudemonia in a tourism context (Fennell 2006; Knobloch, Robertson and Aitken 2016; Pearce 2005).

\section{Volunteer tourism}

Earthwatch was one of the founding organisations that began to promote overseas volunteering in the early 1970s (McGehee 2014). Between 1971 and 2014, this organisation alone has employed 90,000 volunteers in 1400 projects across 120 countries, contributing US\$67 million and 11 million hours to scientific fieldwork (Earthwatch Institute 2008; 2014). In 2008, Tourism and Research Marketing undertook a survey of 300 organisations in the volunteer tourism industry and estimated the market size to be 1.6 million volunteer tourists per year worth, between $£ 832$ 
million and $£ 1.3$ billion in spend. Since then, Mintel (2014) estimates that there were 4 million volunteer tourists worldwide in 2013, spending approximately US\$5 billion.

The most popular destinations for volunteer tourists are Latin America, Asia and Africa, which together account for almost $90 \%$ of locations offered by operators based in affluent countries (Mintel 2014). Mintel (2014) divides the market into three categories: gap-year and university students, aged 18-25; career breakers and young professionals, and the 50+ post-family market. But altruistic, egotistic and eudemonic motives, and other psychographic features are much better indicators of participation than demographic profiles (Clary, Snyder, Ridge, Copeland, Stukas, Haugen and Miene 1998). Above all, volunteer tourists are purpose-driven travellers who seek meaningful journeys (Rogers 2007). Travelling for a purpose is an inherent aspect of volunteer tourism whereby tourists search for physical, emotional or spiritual fulfilment (Callanan and Thomas 2005; Noy 2004). The Hebrew word ‘volunteer' means to 'give willingly', implying money, labour and expertise (Cnaan, Handy and Wadsworth 1996).

However, the United Nation's (2001) definition of volunteering recognises the exchange and reciprocity value: i.e. that the volunteer is also a beneficiary of the activity. Volunteering is often associated with committing a person's services over an 
extended period (Snyder and Omoto 2008), but in consumer-driven, time-poor societies, volunteering is often less committed and more episodic (Wilson 2012). Volunteer tourism is an example of such short-term volunteering.

Callanan and Thomas (2005) propose a conceptual framework, which consists of three types of volunteer: shallow, 'intermediate and deep. These categories are based on six criteria including the destination characteristics, the duration of time spent there, the focus of the experience (i.e. self-interest or altruism), the required qualifications, active versus passive participation, and the level of contribution to locals. NGOs may focus their marketing on deep intrinsically motivated 'volountourists' whilst tour operators may target the more extrinsically motivated shallow volunteers.

In principle, volunteer tourism is a means of assisting communities, species and habitats. It has been applauded for its objectives of building international relations, fostering cross-cultural experiences, promoting tolerance, global awareness and civic engagement as well as supporting tourists’ own personal development (Dykhuis 2010). It can satisfy a longing for adventure and travel whilst providing valuable services to local communities (Bailey and Fernando 2011). Thus, volunteer tourism is promoted as a 'win-win' type of travel where both communities and tourists benefit. But the 
negative aspects of volunteer tourism cannot be ignored with questions over the morals and merits of a growing profit-making sector (Sin 2009) and its tendency to reinforce rationalisations of colonialism and poverty due to the focus on travel to developing countries (Mostafanezhad 2014; Matthews 2008; Raymond and Hall 2008).

However, much has been written about the personal benefits of volunteer travel for the individual. These include overcoming challenges and hardships (Galley \& Clifton, 2004), having novel and unique experiences (Pearce \& Coghlan, 2008), the acquisition of cultural capital (Jones, 2011) and adventure (Stoddart \& Rogerson, 2004). Personal changes that most volunteers experience include: more confidence in travelling independently, increased knowledge, better skills for dealing with challenging situations, a deeper understanding of themselves, changed career direction and a changed view on their lives and the world in general (Broad 2003). Volunteer tourism is therefore personally transforming (Noy 2004), providing authentic and meaningful life experiences that alter attitudes, behaviour, values, knowledge and skills (Alexander 2012). The critics of volunteer travel state that volunteering is more about egoism than altruism: i.e. tourists’ seemingly selfless contributions to local communities and environments are self-serving attempts to boost their own image (Gray and Campbell 2007; Uriely, Reichel and Ron 2003; Wearing 2001). But a less critical proposition is presented by Tomazos and Butler (2012) who suggest that volunteer tourists possess 
multiple motivations simultaneously, and can adopt any position on a continuum between altruism and egotism. This paper is further evidence of this complexity.

\section{Eudemonia and volunteer tourism}

Volunteer travel is therefore different from other forms of travel in so far as it places the tourist in a setting that goes beyond superficial interactions as it often requires deep personal reflection (Lepp 2008), Volunteering can also be positively related to personal evaluations of happiness and well-being given that it is deemed a useful and meaningful experience (Elliott and Coker 2008). The pursuit of happiness has long concerned philosophers, and is still an area of considerable examination today (Diener 2013; Dodge, Daly, Huyton and Sanders 2012; Ryff 2014; Seligman 2011).

There are two prevailing theoretical dimensions of happiness: hedonism and eudemonia. Hedonism concentrates on the maximisation of pleasure and the reduction of pain (Aristotle 2009; Diener 1984; Ryan and Deci 2001). Knobloch, Robertson and Aitken (2016, 653) claim that there is “too much emphasis on equating tourists' happiness with pleasure” and that researchers have neglected the importance of meaningful experiences, emotions and enhanced understanding of self that "reach beyond the time 
spent travelling”. Eudemonia is based on a theory from positive psychology and is relatively new to tourism researchers (Filep and Deery 2010). It is grounded in endeavouring to lead a meaningful life and achieve optimal functioning by being inspired and enriched. Given the purposeful nature of volunteer tourism, an investigation into its eudemonic benefits and motivations (rather than its hedonic qualities) is a vital part of understanding and facilitating this market. It will stress the significance of creating opportunities for people to engage in eudemonic activity that will ultimately lead to enhanced levels of psychological well-being.

Research on volunteer tourist motivations has been extensive. Motivations are mostly categorised under four major themes: cultural immersion (Chen and Chen 2011); camaraderie (Brown 2005); education; and giving back to society (Grabowski and Wearing 2011). Clary et al. (1998) identified similar functional motives. Volunteering is a way to: 1) protect the ego by reducing guilt and overcoming negative self-concept or negative feelings about life, 2) express altruistic and humanitarian values, 3) improve career prospects, 4) develop social ties, 5) gain knowledge and skills, and 6) help the ego grow and develop. These discrete concepts are useful markers in the analysis of motivations. However, a more holistic light can be shed by rooting them in eudemonia. 
Seligman (2011) argues that no single measure defines happiness but several factors contribute to it. For Dodge et al. (2012) happiness is an equilibrium point between two shifting states of challenges and available resources, whereas Deci and Ryan (2000) assert that self-determination, freedom of choice and goal fulfilment are essential ingredients. Seligman’s (2002) theory of 'authentic happiness' suggests that happiness can be measured against three criteria: positive emotion (feeling good), engagement (absorption and flow) and meaning (serving something that is greater than the self).

It is thought that human emotions including happiness vary around a set point that is relatively stable throughout an individual's life. This is derived from genetic disposition and personality and can account for as much as $40-50 \%$ of self-assessed happiness variance (Bartels and Boomsma 2009; Bouchard and Mc-Gue 2003; Lykken and Tellegen 1996). Lyubomirsky, Sheldon and Schkade (2005) propose three primary types of factors that determine one’s happiness: the aforementioned set point, life circumstances and intentional activity. Happiness theorists claim that people make choices according to how much happiness will ensue as a result (Seligman 2011) and that people expect to enjoy a life that is not only happy but meaningful too. 
The hedonic tradition tends to place emphasis on an abundance of positive feelings and life satisfaction (Bradburn 1969; Diener 1984; Kahneman, Diener and Schwartz 1999). Conversely the concept of eudemonia is associated with self- development and a meaningful life which is not necessarily dependent on positive experiences but negative ones too (Waterman 1993; Ryan, Huta and Deci 2008). Hedonic pleasure is perceived to be fleeting (Seligman 2011) whereas eudemonic wellbeing is longer lasting and contributes to self-realization.

Hedonic philosophers such as Epicurus, held that people are motivated by the optimization of individual pleasure (Henderson and Knight 2012). In contrast the eudemonic tradition can be traced back to Aristotle and Plato (Grindle 2012) who believed that happiness and wellbeing are dependent on the fulfilment of potential through the pursuit of individual and social goals (Keyes and Annas 2009). Aristotle defined eudemonia as "a character of persons that entails living in accordance with reason and moderation, and aiming toward excellence and the realization of a complete human life.” (Ryan, Huta and Deci 2008, 143). People cannot be truly well or happy without engaging in self-development and making a contribution to the lives of others (Waterman 1993). There are a number of beneficial outcomes of a eudemonic lifestyle 
including a lasting sense of subjective wellbeing (Ryan et al. 2008), better health (Ryff and Singer 2008) and greater vitality (Ryan and Frederick 1997).

Philosophers often portray hedonism and eudemonism as competing and dichotomous whereas social scientists acknowledge that happiness is achieved through a combination of hedonic and eudemonic pursuits given that a eudemonic lifestyle can lead to hedonic gratification (Huta and Ryan, 2010). They may bring people closer to achieving 'authentic happiness' (Seligman 2002) and 'flourishing' (Seligman 2011), hence the plea for researchers to abandon dichotomous thinking and to recognize that eudemonia and hedonia are mutually inclusive (Henderson and Knight 2012). Indeed, Seligman (2011) includes both perspectives in his model 'PERMA', which relates happiness to engagement, achieved through engrossment in work and leisure; meaning-making, and the achievement of goals. 'PERMA' is an acronym for Positive emotions - feeling good; Engagement - being completely absorbed in activities; Relationships - being authentically connected to others; Meaning - purposeful existence, and Achievement a sense of accomplishment and success.

There is a strong link between eudemonia and the philosophical concept of existential authenticity, which has received much coverage in the tourism literature (see Wang 
1999; Brown 2013). Existentialist philosophy puts emphasis on both the individual's creation of meaning and on the fulfilment of creative potential in order to live authentically (Brown 2013). As Wang (1999) states, if everyday life does not allow the authentic self to be expressed, then tourism is turned to as a route to fulfilment. Volunteering, in particular, can facilitate the mobilisation of meaning-making and the expression of authentic values, as well as being a source of intrinsic pleasure.

There is also a connection with Sartre's focus on commitment to working for a social good: it is easy to see how volunteering may be the form of tourism which best activates a state of authenticity, of achieving both meaning and commitment. With freedom comes the burden of responsibility for actions, whence emerges the notion of engagement (commitment), which demands of people that they take responsibility for ensuring that their actions are beneficial in some way to the common good (Brown 2013).

There have been a number of quantitative studies to show the importance of travel to people’s subjective evaluation of well-being (Sirgy 2010; Uysal, Perdue and Sirgy 2012). Research also exists on different types of holiday products and happiness (Bimonte and Faralla 2012). It is surprising then that more researchers have not applied 
positive psychology to tourist experiences (Pearce 2009; Nawijn 2011). Few studies have considered eudemonia within a tourism context with the exception of Filep and Deery (2010), Coghlan and Fennell (2009), Fennell (2006) Fennell and Malloy (2007), and (Pearce 2009). This study therefore makes an important contribution to the literature on volunteer tourism by using the concept of eudemonia to frame individual tourist experiences. 


\section{Study context and methods}

Although the use of quantitative research is deeply rooted in positive psychology, Filep (2012) calls for greater use of qualitative approaches to understanding happiness within the context of tourist experiences. This study therefore adopted a qualitative approach, and selected the ethnographic method of participant observation. It was felt that by being immersed in the research setting, the researcher (the first author) would have access to participants who would provide a fresh account of their experiences and that she would experience the volunteering phenomenon first hand. DeWalt and DeWalt (2010) note that participant observation is about more than just watching; it is also about listening, speaking and recording documentary evidence. It is for this reason that Strauss and Corbin (1998) see participant observation as qualitative research 'par excellence', as it provides a holistic understanding of the setting. Several researchers claim that valuable insights can be gained by investigating single tourist experiences as close as possible to when they happen rather than relying on delayed recollections (Knobloch et al. 2016) because recollections are deemed unreliable (Braun-La Tour, Grinley and Loftus 2006).

Overseas conservation volunteering is offered by a number of international conservation organisations that combine conservation activities with the opportunity to travel to 
exotic or remote locations. The expedition charity with which the first author travelled was founded in 1969 by a well-known British explorer as a non-profit making organisation that organises a worldwide programme of scientific expeditions, conservation, education and community aid projects. In April 2012, the researcher (the first author) took part in a project to study a herd of wild elephants in Bardia National Park, Nepal, at the same time promoting elephant (and tiger) conservation by supporting and engaging the local population living in the buffer zones of the national park. This was done through running dentistry and medical clinics and raising money to support victims of elephant raids. Volunteers were recruited according to the skill requirements of the project: all members of the expedition were given a specific role according to their expertise.

Nepal is one of the poorest countries in the world but it encompasses a remarkable diversity of habitats and species. The Terai plains in the southern part of the country contain five protected areas, one of which is Bardia National Park which is home to rare and endangered species such as the Bengali tiger (Pantera tigris), the Asian one-horned rhinoceros (Rhinoceros unicornis) and the Asian elephant (Elephas maximus). The people who live in these biodiverse areas have faced problems with involuntary displacement and the restricted rights of access to resources for their livelihood such as the collection of firewood, fodder, and medicinal plants. Local people are also 
threatened by the loss of livestock and crop-raiding by wildlife which, understandably, culminates in local resentment and a general lack of support for conservation (Nyaupane and Poudel 2011). It was hoped that providing medical clinics, fund raising and engaging the local community would help support conservation initiatives; one of which is ecotourism. In spite of being the largest protected area in the Terai, Bardia does not attract as many visitors as Chitwan National Park to the East. Its ecotourism strategy was in the process of being updated and it was the researcher's responsibility to connect with the park managers and assist in updating the strategy.

To comply with research ethics, permission to join the expedition in order to conduct research was sought from the gatekeeper, the leader of the expedition and The Scientific Exploration Society, to which the researcher belongs. The aim of the research was clearly communicated and permission was requested to conduct participant observation and interviews. All twelve volunteers agreed to participate in the research. The decision as to whether to adopt an overt or a covert participant observation stance was given much thought, with particular attention to the observer effect on data quality. Much has been written about the ethics of covert participant observation (see Jones, Brown and Holloway 2013) and in the end, an overt approach to data collection was adopted, with participants being informed of the researcher's aim and identity. A profile of 
participants is offered below. Pseudonyms are used to protect identity, and no identifying information, such as the participants' roles, are used in the research account.

\section{Table 1: Participant profiles (goes here)}

In this study, participation observation took place over a two-week period and involved full immersion (Spradley 1980). Fieldwork was conducted during April/May 2012 when observational data were collected: tasks, events, sightings and day-to-day activities were observed and recorded in the researcher's travel diary. Observations were mostly descriptive allowing the researcher to record events which helped her to place participants' comments into the right event or context ensuring that she could interpret the data correctly. Being a Scientific Exploration Society (SES) expedition, most volunteers, and especially the women, kept a daily diary, so carrying a field book and making frequent notes was not unusual and therefore unobtrusive (Mason 2002).

Twelve in-depth interviews were undertaken over a period of two days towards the end of the trip. A semi-structured, conversational style of interview was adopted (Rubins and Rubins 2012). Lines of enquiry were linked to the research questions set out in the 
introduction and were organised under three a priori themes: 1) motivations for joining the expedition; 2) personal development and meaningful experiences and 3) reflections on the positive and negative emotions experienced during the expedition. Following data collection, a further review of literature was undertaken in an iterative fashion, depending on the themes that emerged from analysis (Jones, Brown and Holloway 2013). As is the norm in inductive qualitative research (ibid), the primary data are discussed in the following section in tandem with the relevant literature.

Thematic analysis was used to analyse the data (see Braun \& Clarke 2006), involving three steps: the transcription of interview and observational data; multiple readings of transcripts; the coding and categorising of data, which fed into the thematic framework (Holton 2007). To improve credibility, this analytic process was conducted by both authors (see Jones, Brown and Holloway 2013). Working together and with ample reflection and discussion of the data, an initial coding framework was devised. 55 open codes from both observation and interview data were organised into 12 axial codes, which were later collapsed into the four major headings: 'the importance of travel'; 'self-orientation (egoism)'; 'orientation towards others (altruism)', and 'happiness, contentment and volunteering'. The open codes make up the content of the discussion. To highlight the findings and signpost the reader, both the 12 axial codes and the 55 open codes that are pertinent (i.e. underpin) to the main headings appear in the thematic diagrams that begin each section. 


\section{Findings and discussion}

\section{The importance of travel for a meaningful life}

The first thing to materialise from the interviews was that participants' desire to travel came before their desire to volunteer. Figure 1 depicts the importance of travel and the resultant psychological benefits as experienced by the expedition participants. The open codes reveal that travel goes beyond escapism and enjoyment (i.e. the hedonistic domains) but also provides lasting benefits and coping mechanisms that spill-over into their everyday lives. Happiness comes from the combination of these meaningful journeys and optimal functioning as a volunteer participant. Place becomes less important than the experience and the knowledge gained from it (both self-knowledge and world views). Purposeful travel also fulfils an inherent sense of adventure but not without apprehensions about physical fitness and the mental capability to withstand discomfort.

\section{Figure 1: The importance of travel for a meaningful life (goes here)}

Travel is a fundamental desire and aspiration. The reasons for this are complex and multi-faceted and range from purely frivolous to deeply philosophical. Participant 
responses range from how travel is "the perfect antidote to my life” (Gavin), "a good distraction from normal life" (Jack), or an "escape from the drudgery of work" (Roger). It is certainly "something to look forward to" (Tim), and a way of "seeing what is going on in the world" (Barry). The consensus is that travel "opens your eyes to how good you have it versus how so much of the rest of the world lives and how difficult life is for so many people around the world”. (Diana). The latter comment runs counter to the belief that travel is purely a hedonistic escape and reflect the nature of the expedition and volunteer tourism market who crave knowledge and self enhancement rather than the avoidance of self-growth and/or challenging environments and cultures. It is also in line with MacCanell's (1976) supposition that some tourists are searching for universal truths and authentic expressions of the world.

For Rosa and Anita the eudemonic outcomes of travel are found in what is brought back to normal life: "I think going to other places makes you look on your own world in a completely different way" (Rosa). The idea that travel provides a new life perspective deserves further research (Falk, Ballantyne, Packer and Benckendorff 2012). Smith and Kelly $(2006,15)$ suggest how “tourists are increasingly using tourism as a means of improving their home life, rather than merely escaping from it”. The impacts of tourism on overall life satisfaction and quality of life have been studied by several authors (Gilbert and Abdullah 2004; Nawijn 2011; Sirgy, Kruger, Lee and Yu 2011). Although 
there is a very strong perception that travel makes one happier, ordinary vacationers do not benefit from vacationing to such an extent that they cope better with everyday life (Nawijn, Mitas, Lin, and Kerstetter 2013). Post trip benefits of vacationing, in terms of evaluations of personal happiness, tend to be short-lived. Conceivably this is the difference between hedonic travel and eudemonic travel; namely that hedonic feelings tend to be short-lived whereas eudemonic feelings are deeper and longer lasting. As Gavin eloquently explains for him "normal holidays are like islands of time”, out of context with your life back home, whereas "trips like this have a more lasting effect on you; especially the friendships you make”.

The expedition volunteers revealed that travel goes beyond escapism and enjoyment (i.e. the hedonistic domains): happiness was felt to be a combination of meaningful journeys and optimal functioning as a volunteer. A search for meaning was an integral aspect of participants' perceptions of purposeful travel. Volunteering was an opportunity to give whilst developing themselves in the process.

\section{Adventure, place and embodiment}


The choice of destination and/or expedition appeared to be relatively unimportant. Instead participants based their decision on "experiencing the jungle” (Rosa), or being “outside of your comfort zone” (Roger). However, participants unanimously highlighted the desire for an authentic and adventurous experience, which tested their fortitude. Discomfort was associated with authenticity, with several participants disappointed that the camping was too "soft" and "glamourous" (Tim). As Gavin explains, "I was hoping it would be more hard-core; chopping our way through jungles, living off the land, and death defying danger!” Adventurous spirits were satisfied however by the setting and "walking in the jungle with the possibility of encountering wild elephants and tigers” (Roger). In addition, the beauty of the landscape, the peacefulness and the soundscapes provided the optimum backdrop for adventure.

De Botton (2002) reminds us that we cannot escape our physical selves when we travel; we inadvertently bring our bodies along too. Whilst most of the expedition volunteers were reasonably fit and healthy; several participants had chronic health conditions that needed careful management. There was also the very real possibility of food related illnesses. Almost everyone shared concerns about their physical abilities and fitness, and the physical demands of the trip took their toll: "It was really mentally challenging being ill because the food poisoning utterly wiped me out to the point where I just wanted to go home. I felt wretched" (Tim). Whilst these underlying concerns were not 
voiced within the group they clearly had an effect on individual participants’ psychological well-being and confidence during the expedition. These feelings were totally self-orientated and were often voiced in relation to a feeling of achievement in overcoming them.

We live in a performance-based culture where goal setting and achievement is highly valued. Jain. Apple and Ellis (2015) claim that stepping outside of one's comfort zone is a critical aspect of self-growth because it requires the traveller to perform at a higherthan-ordinary level. It is significant that the word travel comes from the French word 'travail' meaning 'hard work', 'labour' and 'torment'. Boorstin (1987) reminds us how travel and exploration was once about hardship and this notion lives on in the imagination of the participants; particularly the men (Tomazos and Butler 2012). The imaginative notion of an expedition invokes adrenaline (Cater and Cloke 2007) i.e. hacking through the jungle, avoiding, snakes, etc and self-denial; roughing it is cathartic. Jungles are exotic and sublime and afford heat, wildness and space for selfrealisation (Lorimer 2010). However, fears about being physically unable to manage the challenges on tour sit alongside the positive connotations. This is not a wellresearched aspect of volunteer travel but these comments highlight self-doubts about fitness, obesity and general health; all aspects to overcome in the development of self and a meaningful outcome. 


\section{Self-orientation}

Figure 2 represents participants' responses to how the trip was developing them as an individual. These thoughts came from self-reflection and self-awareness of being an expedition volunteer and included understanding their strengths and weaknesses, a recognition from others and feeling a sense of achievement.

\section{Figure 2: Self-orientation (goes here)}

\section{Developing the self}

The expedition allowed many of the participants to learn more about themselves, which they believed enabled them to be better people on their return. As Richard explains: "over time travel like this reduces the hideous arrogance and self-importance. It makes me very tolerant and more compliant with everyone's everyday life. You're out of your comfort zone, you're out of the city and you are out of the west”.

Thus, the expedition was not only a geographical journey but also a personal one in which participants often questioned their ability to work as a team, to get on with people 
from all walks of life, to be less sanctimonious and to cope with physical discomforts. There was a palpable sense of achievement over being able to do something perceived as worthwhile. Travelling with a famous explorer also provided one or two participants with social kudos that boosted self-esteem.

Opportunities came and went for participants to reflect on their strengths and weaknesses, skills and personality traits that could be enhanced or moderated for the benefit of others. As Ruth commented, these moments of truth and reflection helped her to "understand myself better... what I like and what I need". Often participants suggested that they liked themselves more for volunteering their services: "I feel good that I have been able to help them (patients) and I am proud of myself for having gone and done it, and I am really grateful that I had the opportunity” (Barry).

Such self-understanding and esteem supports the research by Son and Wilson (2012) which found that volunteer work is partly motivated by a desire to strengthen selfconcept, to learn more about oneself, to grow personally, and to build self-confidence. Volunteering is also likely to have a more enduring effect on eudemonic well-being because eudemonia consists of a reconceptualization of the self (Bruyere and Rappe 2007). 
Adaptability was an aspect of self that was universally applauded particularly in the acceptance of local norms and improved empathy; this culminated in a "good boost to your confidence and self-esteem” (Tim). However, people’s perceptions of themselves were not always positive. There was a constant evaluation of personal limitations: “sometimes you think you can do something and it turns out that you can't” (Tim).

McGehee (2002) similarly found that volunteer travel increased positive feelings of self-efficacy. Self-efficacy is the inner belief as to how much an individual has the internal resources such as ability, talent, skill, resourcefulness, endurance and willpower needed to perform successfully (Bandura 1997). Optimal psychological functioning and eudemonic happiness are arguably reliant on positive personal assessments and especially feeling an able and valuable member of a group or society. This expedition allowed self-efficacy to develop as it facilitated a safe place for personal growth experimentation. As Rosa found, "if I push myself a little bit further then I enjoy myself more".

\section{'Understanding myself'}


This study shows that travel provides a physical and mental space to "just be yourselfit's very freeing” (Jack) or "to reclaim your soul” (Gavin). The awareness of self is very prominent in this study with some participants apologising for the seemingly

egotistical focus on the self. Ruth commented on the link to self-expression: "there is $a$ selfish aspect in as much as travelling allows me to be me. I find a different part of myself and it is a selfish thing”. Travel offers a liminal space where there is temporality and an anonymity that frees the spirit from the expectations of self and others. The absence of everyday ‘duty’ and time pressures provides space for self-reflection and personal growth (Desforges 2000; Elliot and Coker 2008; Lepp 2008). That said, in volunteer tourism, the tourist is subject to new rules and obligations that may exert new demands on the self and negate this apparent 'freedom'. This is because the group (team) situation of expedition volunteering requires orientation towards others.

\section{Orientated towards others}

Self-reflection is one's evaluation of oneself often in relation to others. By its very nature volunteer expeditions, which work with local communities, require interaction with local people and team members and therefore, much movement in selfdevelopment and self-awareness stems from the need to get on with others. As Barry explains: "on an expedition such as this it is incumbent upon you to try to get on with 
people you are working with; to relate to them the best you can and to work together. It's not like we are all on a holiday where you really couldn't care less”. This was a dominant theme within the interviews, as the data in Figure 3 reveal. Furthermore, participants needed to feel useful, that they were positively contributing. There were frustrations often caused by a lack of autonomy within the team and the blurred boundaries between feeling employed and being 'on holiday' especially given the comfortable conditions at camp and the cost of the trip.

\section{Figure 3: Orientation towards others (goes here)}

\section{Getting on with others: 'will I fit in?'}

Whilst the absence of significant others provided liberation from everyday roles and the mental space to contemplate new ways of being, getting on with people was a fundamental and universal concern for expedition participants. How to fit in was a common concern prior to the trip. Overcoming this fear and getting on with everyone was often seen as an achievement: “I learned to get on with people I wouldn't have dreamed I would ever get on with. You know, I'm very proud of myself for that. I've crossed a lot of bridges and I think I'll come away a better person for it” (Gavin). Participants voiced concerns over the challenge as well as the benefits of interaction. 
Indeed, for most, learning to get on with others in the team was perceived as a fundamental benefit of the trip. Any self-doubts were rooted in the desire for approval.

Keyes (2006) argues that eudemonia consist of both private and public facets of positive functioning and social interaction. Individuals must feel they belong to, and are accepted by, the communities they function in, and see themselves as having something worthwhile to contribute. In addition, they must also feel that they can accept other people (social acceptance).

\section{Feeling useful}

Feeling useful was critical to the eudemonic outcomes of being on the trip. Although there was a selection process to join the expedition, some of the participants worried about how much they could contribute: "everyone is going to be a doctor, dentist, engineer, and I'm none of the above” (Roger). "Am I qualified enough? What will my duties be?" (Gavin). The researcher also experienced self-doubts, as this entry in her journal describes. This extract was written during a trip to a local school: "I managed to talk to a few of the school teachers and children through a lot of smiles and sign language but it all felt rather awkward and embarrassing. What am I doing here? The 
dentists and the doctors have set up a clinic and are working non-stop in the heat, treating an endless line of patients whilst I am here not contributing”.

It became clear on the expedition that such feelings ran deep for several participants. Proving one's worth whilst in the field was a source of anxiety, and Rosa articulated a common concern: "It's important to me that I have a proper place within the expedition. I didn't want to come as a tourist”. Among those whose skills were in demand, there was concern about living up to the expectations that their role demanded. Being valued was therefore of upmost importance, as Campbell (2011) also notes.

\section{Blurred understandings: holiday or work?}

Given the financial cost of participating in voluntourism, several participants questioned the blurring and confusion between volunteering and vacationing. Roger sums up the experience simply but effectively: "it was a holiday of a lifetime but with a purpose". Others were slightly more critical of the outcomes, as James observes: “it's a bit of a middle-class holiday but you can feel as though you are doing some good by being here.". 
Stebbins (1996) has articulated well the notion of the blurred boundary between work and leisure; namely that for many people leisure time is used to enhance certain skills and accomplishments. Indeed, he was the first to write about volunteering and serious leisure pursuits, given that volunteering is associated with labour and productivity, and yet it is undertaken during a person's free time and is unpaid, or as in the case of this expedition, incurs considerable costs for the volunteer. Tomazos and Butler (2012) explored the blurred boundaries between the task of the volunteer travel and the 'holiday' experience, claiming that the volunteering experience consists of more than just work duties. In addressing this work-pleasure balance, they propose a motivational see-saw model which suggests that participants, "whatever their initial motivations or intentions, when presented with the leisure/fun element of the experience, are vulnerable to succumbing to the hedonistic pursuits available” (ibid:185). This dynamic is exemplified in an episode in the researcher's journal where participants felt aggrieved that one jeep could stay and observe a wild herd of elephants whilst the other was sent away on a seemingly boring or pointless task. This provoked an internal conflict over whether participants wanted to be 'ordinary' tourists enjoying a lifetime opportunity of watching wild elephants or to be more mundanely useful.

\section{Happiness, contentment and volunteering}


When participants were asked what aspects of the trip had given them the greatest feelings of happiness, most responses centred around wildlife rather than volunteering or conservation: "The happiness for me came from the fact that at times you think, oh I'm sitting here on an elephant in the pool on safari, it's like how am I here, how have I got myself here” (James).

Feelings of happiness and contentment were also attributed to being useful, suggesting a eudemonic outcome, and to social interaction, as articulated by Richard: "I enjoy being with people that are on similar wavelengths.... Every day is just happiness”.

There was a sense of privilege to have joined the expedition alongside uncomfortable echoes of imperialistic or colonial ideals, particularly with regards to elephant conservation, the impact of this on local people, the blurring between holiday and volunteering and the feeling of only having made a small, short-term difference.

Figure 4: Happiness, contentment and volunteering

Such sentiments are reflected in the literature on volunteer tourism. Lorimer (2010) takes a very critical view of conservation volunteer expeditions such as this. His paper 
claims that they are evidence of the 'neoliberalisation' of environmentalism. He refers to an uneven conservation geography in which volunteer tourists from the UK are sent. For example, “a country must be poor enough to keep costs down, but stable enough to ensure that volunteers have a safe trip” (2010, 314). This “uneven geography”, he claims, is deeply interwoven with the history of colonialism, which configured and continues to influence the geographies of international tourism, conservation and development (Mowforth and Munt 2008). Nepal is a fitting example. Moreover, the short-term nature of the medical assistance offered in volunteer tourism is reflected in both the literature (see Sin 2009), and in participants' comments. As Anita stated: “I don't feel any, sort of sense of warmth for helping them. I didn't go out there to think I was going to change these people's lives by pulling out some teeth. I don't think what we did is sustainable unless the clinics are run more frequently".

The relationship between neo-colonialism and volunteer tourism has been espoused by several authors on volunteer travel. Butcher and Smith (2015) suggest that volunteer travel is a consumer choice driven by an aspiration to adopt an ethical lifestyle and to be part of new moral economies whilst Mostafanezhad (2014) argues that volunteer tourism works to map out a geography of compassion that extends imperial legacies of colonialism and uneven development. The participants in this experience of volunteering were not typical young gap year volunteers, they were mature, politically aware and sensitive to the wider issues of developing countries. Their eyes were open to 
the realities of the situations they found themselves in and the privileged backgrounds from which they had come. For some, this political awareness became the lens through which they measured their experiences. This is reflected in Gavin’s misgivings about a trip to a village, which 'felt too colonial'.

\section{Time for reflections}

The most unanimous reason for inner happiness, however, came from the sense of feeling lucky and privileged. Almost everyone had overwhelming feelings of how lucky they were to be able to take part, as articulated by Roger: "privileged I think is a word I'll use an awful lot for having experienced this and living to tell the tale” Equally, nearly everyone felt lucky to "grow up in the West in a privileged background, having had free education and decent health care. You look at the way people are living here and you think, you know, some people just don't know they are born back at home” (Rosa). Such feelings of gratitude are a key source of overall life satisfaction (Seligman 2011).

The overwhelmingly positive response to their unique and privileged travel experience was tempered by awareness that returning home could be uncomfortable for 
participants. Their trip could catalyse feelings of guilt, as Ruth observes: "I sometimes worry that it makes me seem a little aloof or elitist because I'm off doing these things whereas other people can't afford to do them" Tim meanwhile worried that he would not be able to share his experiences, whilst Roger felt there was a danger of boring or alienating people. Gavin also referred to the alienating impact of being unable to enjoy common memories, to the damaging effect on relationships at home: "I think it makes it very hard to live with ordinary people in an ordinary life - you begin to feel dissatisfied with ordinary company - because you have lived with such special people and through a wealth of special experiences that the everyday life and people seem extra mundane”.

Disconcerting feelings about re-entry are not unusual. Mitas, Yarna, Adams and Ram (2012) refer to the peak model, which suggests that positive emotions increase until mid-point through the trip; at which point they begin to dip; this is followed by a decline in positive emotions upon return to everyday life. Grabowski and Wearing's (2011) study similarly reveals that the return home is not always easy, whilst McGehee and Santos (2005) report similar findings to this study where participants feel isolated from their peers who cope by maintaining contact with those with whom they had shared the experience. The phenomenon of 're-entry shock' has been most covered in the literature on educational tourists, with research finding that international students 
commonly experience difficulty in readjusting to life in the home country following an often life-changing sojourn in a new culture (see Brown 2009). 


\section{Conclusions}

This paper exposes the eudemonic outcomes of volunteering that are informed by an investigation into individual volunteering experiences whilst on a conservation expedition in Nepal. This offers a new perspective on volunteer travel, moving beyond the tendency towards polarisation of egoism and altruism. By focusing on eudemonia in a tourism context, this ethnographic study marks a new departure in studying volunteer tourism, particularly in terms of what aspects of the experience are felt to be potentially enduring and personally meaningful in terms of living a virtuous life. The volunteers in this study fit the notion of a 'deep' volunteer; given the destination characteristics, the focus of the experience, the required qualifications, the active participation, and finally, the level of contribution to locals. The data revealed the meaningful outcomes of the trip which have a potential impact on their lives beyond the short-term experience.

Yet volunteer, or purposeful, travel is fraught with paradox; it is about escapism, personal growth, a quest to better understand the world and to make a contribution. There is thus a blurred boundary between work and leisure, and sometimes this was problematic. This study suggests that hedonic and eudemonic pursuits both play an 
important role in the promotion of wellbeing. Optimal experiences of wellbeing may therefore be associated with striking a balance between the two.

This study also noted the importance of feeling virtuous which could only be mobilised if participants felt themselves to be useful. It shows that eudemonic outcomes are facilitated only when an individual feels useful and engaged in the overall project and not a passive or ill-equipped observer. Providers of the volunteer expedition experience should therefore be mindful that volunteers need to be made to feel useful and that for deep volunteer tourists the search for meaning should not be under-estimated. Shortterm projects that are geared more to profit than sustainable outcomes would not appeal to this market. Travel is used to connect with and understand the wider world. Rather than an escape, these journeys allow them to experience first-hand the hardships and realities of people in other countries, and this helps to put a sense of reality or perspective on life back home; ideally making them 'better people' on their return.

Finally, this study highlighted a potential difficulty among volunteers in returning home due to an inability to share their momentous experiences and to settle back into what is seen as ordinary life. Research on volunteer travel is growing but what is perhaps lacking is an understanding of how participants re-enter and adjust to everyday life, and 
the long-term effects of their volunteer expedition experience. This paper ends then with a call for future research on how volunteering impacts on individual lives in the long term, with a focus on changes in relationships, in future holiday-taking, in profession, and in self-definition. 


\section{References}

Alexander, Z. 2012. International Volunteer Tourism Experience in South Africa: An Investigation into the Impact on the Tourist. Journal of Hospitality Marketing and Management, 21 (7): 779-799.

Aristotle. 2009. The Nicomachaen Ethics. Translated by David Ross; revised with an introduction and notes by Lesley Brown. New York: Oxford University Press.

Bailey, A. W., and K. I. Fernando. 2011. Decoding the Voluntourism Process: A Case Study of the Pay It Forward Tour. Journal of Experiential Education 33(4): 406-410.

Bandura, A. 1997. Self-efficacy: The exercise of control. New York: Freeman.

Bartels, M., and D. I. Boomsma, 2009. Born to be happy? The etiology of subjective well-being. Behavior Genetics 39: 605-615.

Bimonte, S., and V. Faralla, 2012. Tourist Types And Happiness A Comparative Study In Maremma, Italy. Annals of Tourism Research 39 (4): 1929-1950.

Blasi, A. 1980. Bridging moral cognition and moral action: A critical review of the literature. Psychological Bulletin, 88: 1-45.

Boorstin, D. 1987, The Image: A Guide to Pseudo-Events in America, New York: Atheneum. 
Bouchard, T. J. Jr., and M. McGue, 2003. Genetic and environmental influences on human psychological differences. Journal of Neurobiology 54: 4-45.

Broad, S. 2003. Living the Thai life: A case study of volunteer tourism at the Gibbon Rehabilitation Project, Thailand. Tourism Recreation Research, 28(3), 63-72

Bradburn, N. M. 1969. The structure of psychological well-being. Oxford: Aldine.

Braun-LaTour, K., M., Grinley, and E. Loftus. 2006. “Tourist Memory Distortion.” Journal of Travel Research 44 (4): 360-67.Braun, V., and Clarke, V. (2006) Using thematic analysis in psychology. Qualitative Research in Psychology 3(2): 77-101.

Brown, S. 2005. Traveling with a purpose: Understanding the motives and benefits of volunteer vacationers. Current Issues of Tourism, 8(6): 479-496.

Bruyere, B., and S. Rappe. 2007. Identifying the motivations of environmental volunteers. Journal of Environmental Planning and Management. 50(4): 503-516.

Butcher, J., and Smith, P. 2015. Volunteer Tourism: The Lifestyle Politics of International Development. London: Routledge.

Callanan, T., and S. Thomas, 2005. Volunteer tourism: Deconstructing volunteer activities within a dynamic environment. In Niche Tourism: contemporary Issues, Trends and Cases edited by M. Novelli. 133-144. Amsterdam: Elsevier. 
Campbell, A. 2011. The importance of being valued: Solo 'grey nomads' as volunteers at the National Folk Festival Annals of Leisure Research 12(3-4): 277-294.

Cater, C., and P. Cloke. 2007. Bodies in action: The performativity of adventure tourism. Anthropology Today. 23(6): 13-16.

Chen, L., and J. S Chen. 2011. The motivations and expectations of international volunteer tourists: A case study of “'Chinese Village Traditions”' Tourism Management 32(2): 435-442 .

Clary, E. G., M. Snyder, R. D. Ridge, J. Copeland, A. A. Stukas, J. Haugen, J., and P. Miene, 1998. Understanding and assessing the motivations of volunteers: A functional approach. Journal of Personality and Social Psychology 74(6): 1516-1530.

Cnaan, R. A., F. Handy, and M. Wadsworth. 1996. Defining Who is a Volunteer: Conceptual and Empirical Considerations. Nonprofit and Voluntary Sector Quarterly 25(3): 364-383.

Coghlan, A., and D. Fennell. 2009. Myth or Substance: An examination of altruism as the basis of volunteer tourism. Annals of Leisure Research 12(3-4):377-402.

de Botton, A. 2002. The art of travel. New York: Hamish Hamilton. 
Deci, E. L., and R. M. Ryan.2000. The "What" and "Why" of Goal Pursuits: Human Needs and the Self-Determination of Behavior. Psychological Inquiry 11(4): 227-268.

Desforges, L.2000. Traveling the World: Identity and Travel Biography. Annals of Tourism Research 27(4): 926-945.

DeWalt, K. M., and B. R. DeWalt. 2010. Participant observation: A guide for fieldworkers (2nd ed.).Walnut Creek, CA: Altamira Press.

Diener, E. 1984. Subjective well-being. Psychological Bulletin 95(3): 542-575.

Diener, E. 2013. The Remarkable Changes in the Science of subjective Well-Being. Perspectives on Psychological Science. 8(6): 663-666.

Dodge, R., A. P. Daly, J. Huyton, and L. D. Sanders. 2012. The challenge of defining well-being. International Journal of Wellbeing 2(3): 222-235.

Dykhuis, C. 2010. Youth As Voluntourists: A Case Study of Youth Volunteering In Guatemala. The Canadian Undergraduate Journal of Development Studies, 7(3): 2010.

Earthwatch Institute. http://www.earthwatch.org/earthwatch factsheet (accessed April 17, 2008).

Earthwatch Institute. http://earthwatch.org/about/fast-facts\#The-Figures (accessed February 26, 2014). 
Eliot, I., and Coker , S. (2008) A. Independent self-construal, self-reflection, and selfrumination: A path model for predicting happiness Australian Journal of Psychology, 60(3), 127-134.

Falk, J. H., R. Ballantyne, J. Packer and P. Benckendorff, 2012. Travel and Learning: A Neglected Tourism Research Area. Annals of Tourism Research 39(2): 908-927.

Fennell, D. A. 2006. Tourism ethics. Clevedon, UK: Channel View Publications

Fennell, D. A., and D. Malloy, D. 2007. Codes of Ethics in Tourism: Practice, Theory, Synthesis. Clevedon: Channel View Publications.

Filep, S. J. 2012 Moving Beyond Subjective Well- Being: A Tourism Critique Journal of Hospitality and Tourism Research 38(2): 266-274.

Filep, S., and M. Deery, 2010. Towards a picture of tourists' happiness. Tourism Analysis 15(4): 399-410.

Galley, G., \& Clifton, J. 2004. The motivational and demographic characteristics of research ecotourists: Operation Wallacea volunteers in Southeast Sulawesi, Indonesia. Journal of Ecotourism, 3(1), 69-82.

Gilbert, D., and J. Abdullah. 2004. "Holidaytaking and the Sense of Well-Being.” Annals of Tourism Research 31 (1): 103-21. 
Grabowski , S., and S. Wearing. 2011. Volunter tourism, acculturation and re-entry: the blend of three concepts. In M. Gross, B. Broughton, and T. Morganella (Eds)

CAUTHE. Proceedings of the $21^{\text {st }}$ annual CAUTHE conference, 8-11 February, Adelaide.

Graburn, N. 2001. Secular ritual: A general theory in tourism. In V. L. Smith and M. Brent (Eds) Hosts and guests revisited: Tourism issues of the $21^{\text {st }}$ century. New York: Cognizant Communications.

Gray, N. J., and L. M. Campbell. 2007. A Decommodified Experience? Exploring Aesthetic, Economic and Ethical Values for Volunteer Ecotourism in Costa Rica. Journal of Sustainable Tourism 15(5):463-482.

Henderson, L. W., and T. Knight. 2012. Integrating the hedonic and eudaimonic perspectives to more comprehensively understand wellbeing and pathways to wellbeing. International Journal of Wellbeing 2(3): 196-221.

Holton, J. A. 2007. The coding process and its challenges. In The Sage handbook of grounded theory edited by A. Bryant, and K. Charmaz.. 265-289. Thousand Oaks, CA: Sage Publications. 
Huta, V., and R. M. Ryan. 2010. Pursuing pleasure over virtue: the differential and overlapping well-being benefits of hedonic and eudomonic motives. Journal of Happiness Studies 11: 735-763

Jain, C. R., D. K. Apple and W. Ellis. 2015. What is Self Growth? International Journal of Process Education 7 (1): 41-52.

Jones, A. 2011. Theorising international youth volunteering: Training for global (corporate) work? Transactions of the Institute of British Geographers, 36(4), 530-544

Jones, S. R., V. Torres and J. Arminio, 2013. Negotiating the Complexities of Qualitative Research in Higher Education. London: Routledge.

Kahneman, D., E. Diener and N. Schwarz. 1999. Well-being: the foundations of hedonic psychology. New York: Russell Sage Foundation.

Keyes, C. L. 2006. Subjective well-being in mental health and human development research worldwide: An introduction. Social Indicators Research 77:1-10.

Keyes, C. L., and J. Annas, 2009. Feeling good and functioning well: distinctive concepts in ancient philosophy and contemporary science. The Journal of Positive Psychology, 4(3): 197-201. 
Knobloch, U., K. Robertson and R. Aitken. 2016. Experience, Emotion, and Eudaimonia: A Consideration of Tourist Experiences and Well-being. Journal of Travel Research 56(5):651-662.

Lepp, A. 2008. Discovering self and discovering others through the Taita Discovery Centre Volunteer Tourism Programme, Kenya. In Journeys of discovery in volunteer tourism edited by K. Lyons and S. Wearing ,86-100, Wallingford, UK: CABI International.

Lorimer, J. 2010. International conservation ‘volunteering’ and the geographies of global environmental citizenship. Political Geography 29(6): 311-322.

Lykken, D.T., and A.Tellegen, 1996. Happiness is a stochastic phenomenon. Psychological Science, 7: 186-189.

Lyubomirsky, S., K. M. Sheldon, and D. Schkade, 2005. Pursuing happiness: The architecture of sustainable change. Review of General Psychology 9 (2): 111-131. MacCannell, D. 1976. The Tourist: A New Theory of the Leisure Class. New York: Schocken Books.

Mason, J. 2002. Qualitative researching (2nd ed.). London: Sage Publications. 
Matthews, A. 2008. Negotiated selves: Exploring the impact of local-global interaction on young volunteer travellers. In Journeys of discovery in volunteer tourism edited by K.D. Lyons and S. Wearing, 101-117, Wallingford: CAB International.

McGehee, N. 2002. Alternative tourism and social movements. Annals of Tourism Research, 29(1):124-143.

McGehee, N. G. 2014. Volunteer tourism: evolution, issues and futures. Journal of Sustainable Tourism 22(6): 847-854

McGehee, N., and C. A. Santos. 2005. Social change, discourse and volunteer tourism. Annals of Tourism Research 32(3): 760-779.

Mintel. 2014. Volunteering in Sub-Saharan Africa - May 2014.

http://academic.mintel.com/display/680886/\#. (accessed on March $\left.1^{\text {st }}, .2016\right)$.

Mitas, O., C. Yarnal, R. Adams and N. Ram. 2012. Taking a "Peak” at Leisure Travelers Positive Emotions. Leisure Sciences 34: 115-135.

Mowforth, M., and I. Munt. 2008. Tourism and sustainability: Development, globalization and new tourism in the Third World (3rd ed.). London: Routledge.

Mostafanezhad, M. (2014) Volunteer Tourism: Popular Humanitarianism in Neoliberal Times. Routledge: London and New York. 
Nawijn, J. 2011. Determinants of Daily Happiness on Vacation. Journal of Travel Research 50(5): 559-566.

Nawijn J., O. Mitas, Y. Lin, and D. Kerstetter. 2013. How Do We Feel on Vacation? A Closer Look at How Emotions Change over the Course of a Trip. Journal of Travel Research 52(2): 265-274.

Noy, C. 2004. This Trip Really Changed Me: Backpackers’ Narratives of Self-Change. Annals of Tourism Research 31(1): 78-102.

Nyaupane, G. P., and S. Poudel. 2011. Linkages among biodiversity, livelihood, and tourism. Annals of Tourism Research 38(4): 1344-1366.

Pearce, P. L. 2005. Tourist Behaviour: Themes and Conceptual Scheme. Clevedon: Channel View Publications.

Pearce, P. L. 2009. The relationship between positive psychology and tourist behaviour studies. Tourism Analysis 14(1): 37-48.

Pearce, P. L., \& Coghlan, A. 2008. The dynamics behind volunteer tourism. In K. D. Lyons \& S. Wearing (Eds.), Journeys of discovery in volunteer tourism (pp. 130-143). Wallingford: CABI 
Raymond, E. M., and C. M. Hall. 2008. The Development of Cross-Cultural (Mis)Understanding Through Volunteer Tourism. Journal of Sustainable Tourism 16(5): 530-543.

Rogers, M. 2007. Volunteerism is on the rise: purpose-driven travelers seek meaningful journeys. Travel Agent 331(3): 20-24.

Rubins, H.J., and I. S. Rubins. 2012. Qualitative Interviewing: The Art of Hearing Data. Third Edition. London: Sage Publications.

Ryan, R. M., and E. L. Deci. 2001. On Happiness And Human Potentials: A Review of Research on Hedonic and Eudaimonic Well-Being Annual Review of Psychology 52: $141-66$.

Ryan, R. M., and C. Frederick. 1997. On Energy, Personality, and Health: Subjective Vitality as a Dynamic Reflection of Well-Being. Journal of Personality 65 (3): 529_ 565.

Ryan, R. M., V. Huta, and E. L. Deci. 2008. Living well: a self-determination theory perspective on eudemonia. Journal of Happiness Studies 9 (1): 139-170.

Ryff, C. D. 2014. Psychological Well-Being Revisited: Advances in the Science and Practice of Eudemonia. Psychotherapy and Psychosomatics 83(1):10-28. 
Ryff, C. D., and B. H. Singer. 2008. Know thyself and become what you are: a eudemonic approach to psychological well-being. Journal of Happiness Studies 9 (1): 13-39.

Scientific Exploration Society. Available at http://www.ses-explore.org/ (accessed June 16, 2017).

Seligman, M. E. P. 2011. Flourish: A New Understanding of Happiness and WellBeing - and How to Achieve Them. London: Nicholas Brealy Publishing.

Seligman, M. E. P. 2002. Authentic happiness: Using the new positive psychology to realise your potential for lasting fulfilment. New York: Free Press.

Sin, H. L. 2009. Volunteer Tourism:“'Involve Me And I Will Learn’’? Annals of Tourism Research 36(3): 480-501

Sirgy, M. J. 2010. Toward a quality of life theory of leisure travel satisfaction. Journal of Travel Research 49(2): 246-260.

Sirgy, M. J., P. S. Kruger, D. J. Lee, and G. B. Yu. 2011. How Does a Travel Trip Affect Tourists’ Life Satisfaction? Journal of Travel Research 50(3): 261-275.

Smith, M., and C. Kelly. 2006. Wellness Tourism. Tourism Recreation Research 31(1): $1-4$. 
Snyder, M., and A. M. Omoto. 2008. Volunteerism: social issues perspectives and social policy implications. Social Issues and Policy Review 2(1): 1-36.

Son, J., and J. Wilson. 2012. Volunteer Work and Hedonic, Eudemonic, and Social Well-Being. Sociological Forum 27(3): 658-681

Spradley, J. P. 1980. Participant Observation. Belmont, C. A.: Wadsworth: Cengage Learning.

Stebbins, R. A. 1996. Volunteering: A Serious Leisure Perspective. Nonprofit and Voluntary Sector Quarterly 25(2), 211-224.

Stoddart, H., \& Rogerson, C. M. 2004. Volunteer tourism: The case of habitat for humanity South Africa. GeoJournal, 60(3), 311-318

Strauss, A., and J. Corbin, J. 1998. Basics of qualitative research: Techniques procedures for developing grounded theory (2nd ed.). Thousand Oaks: Sage Tomazos, K., and R. Butler. 2012. Volunteer tourists in the field: A question of balance? Tourism Management 33: 177-187

UN (2001) Commission for Social Development. Report on the thirty-ninth session E/2001/26. E/CN.5/2001/9. New York: United Nations. 
Uriely, N., A. Reichel, and A. Ron. 2003. Volunteering tourism: additional thinking. Tourism Recreation Research, 28(3): 57-62.

Uysal, M., R. Perdue, and J. Sirgy. 2012. Tourism and Quality of Life Research: The Missing Links. In The Handbook of Tourism and Quality-of-Life Research: Enhancing the Lives of tourists and Residents of Host Communities edited by M. Uysal. R. Perdue and J. Sirgy, Chapter 1, New York: Springer Dordrecht.

Wang, N. 1999. Rethinking authenticity in tourism experience. Annals of Tourism 26(2): 349-370.

Waterman, A. S. 1993. Two conceptions of happiness: Contrasts of personal expressiveness (eudaimonia) and hedonic enjoyment. Journal of Personality and Social Psychology, 64 (4):, 678-691.

Wearing, S. 2001. Volunteer tourism: Experiences that make a difference. Oxon, UK: CABI Publishing.

Wearing, S. 2003. Re-centering the self in volunteer tourism. In The tourist as a metaphor of the social world edited by G. M. S. Dann, 237-263, Oxon, UK: CABI. Wearing, S., and N. G. McGehee. 2013. Volunteer Tourism: A review. Tourism Management 38: 120-130. 
Wilson , J. 2012. Volunteerism Research: A Review Essay. Nonprofit and Voluntary Sector Quarterly 41(2): 176-212.

Young, T. 2008. Mediating Volunteer Tourism Alternatives: Guidebook 